\section{PISA Sonuçları Türkiye'deki Eğitim Eşitsizliği Hakkında Neler Söylüyor?}

\section{Özlem Özbey DEMIR'}

\begin{abstract}
Özet
Dünya genelinde eğitim alanındaki en büyük sorunlardan biri de eğitim eşitsizliğidir. Eğitimde eşitsizliği; cinsiyet temelli eşitsizlikler, sosyoekonomik altyapıdan kaynaklanan eşitsizlikler, etnik kökene dayanan eşitsizlikler ve okul-öğretmenden doğan eşitsizlikler olarak sınılandırmak mümkündür. Cinsiyet temelli eşitsizliklerin temelinde toplumun yüzyıllardır bireylere yüklediği cinsiyet temelli görevlerin, sosyoekonomik temelli eşitsizliklerin zemininde bireylerin okul öncesi dönemde aileden aldıkları temel eğitimin, etnik kökene dayalı eşitsizliklerde de dil faktörünün büyük etkisi olduğu görülmektedir. Yaşanan eğitim eşitsizliğinin asıl neden ve nedenlerinin neler olduğunu tespit etmek, eşitliği sağlama yolunda uygulanacak politikaları ve alınacak kararları belirleyebilmek için önemlidir. Eğitim eşitsizliği düzeyini ve bunun altında yatan nedenleri belirlemek adına kullanılan araçlardan biri PISA sınavlarıdır. Bu çalışmada Türkiye için eğitimde eşitsizlik kavramı PISA sonuçlarının değerlendirilmesiyle farklı boyutlarıyla tartışılacak, nedenleri ve çözümleri üzerinde durulacaktır.
\end{abstract}

Anahtar kelimeler: eğitim eşitsizliği, cinsiyet temelli eşitsizlik, etnik kökene dayalı eşitsizlik, sosyoekonomik eşitsizlik, PISA.

\section{What Do The PISA Results Say About Education Inequality in Turkey?}

\section{Abstract}

One of the biggest problems in the field of education around the world is educational inequality. It is possible to classify inequality in education as gender-based inequalities, inequalities arising from socio-economic background, inequalities based on ethnic origin, and inequality arising from school-teacher differences. While gender-basedduties that society has imposed on individuals for centuries have been seen on the basis of gender-based inequalities, the basic education that individuals receive from their families in the preschool period has a great effect on the basis of socioeconomic based inequalities. Moreover, it is seen that the language factor has a great effect on inequalities based on ethnic origin. It is important to determine the main reasons and causes of educational inequality in order to determine the policies to be implemented and the decisions to be taken to achieve equality. PISA exams are one of the tools used to determine the level of educational inequality and its underlying causes. In this article, the concept of educational inequality in Turkey will be discussed with the evaluation of PISA results, its different dimensions, causes and solutionswill be emphasized.

Keywords: educational inequality, gender-based inequality, ethnic inequality, socioeconomic inequality, PISA.

1 YL ögrencisi, İstanbul Medeniyet Üniversitesi, ozlem.ozbey@hotmail.com ORCID: 0000-0002-44721403

Boğaziçi Üniversitesi Ortaöğretim Matematik Fen Alanları Lisansla Birleștirilmiş Tezsiz Yüksek Lisans Fizik Ögrretmenliği programından mezundur. İstanbul Medeniyet Üniversitesi Lisansüstü Eğitim Enstitüsü Eğitim Kurumları İşletmeciliği Bölümünde hâlen yüksek lisans eğitimine devam etmekte, aynı zamanda özel bir lisede IB DP fizik öğretmenliği ve CAS Koordinatörlüğü görevlerini yürütmektedir. http://dx.doi.org/10.22596/ cresjournal.0102.85.98

\section{Derleme}

\section{Review}

Başvuru/Submitted

18 Kas/Nov 2020

Kabul/Accepted

19 Kas/Nov 2020

Yayın/Published

21 Ara/Dec 2020

ISSN

2718-0808

Atıf/Cite: Demir, Ö.Ö. (2020). PISA Sonuçları Türkiye'deki Eğitim Eşitsizliği Hakkında Neler Söylüyor?. Alanyazın, 1(2), 85-98. 


\section{Giriş}

Günümüzde dünyanın birçok farklı ülke ve bölgesi incelendiğinde yaşanan teknolojik ilerlemelere rağmen eşitsizlik oldukça sık görülmekte olan bir sorundur. Psacharopoulos'a (1981) göre eşitsizliği okuldan önce, okul döneminde ve okul sonrası olarak incelemek mümkündür. Okul öncesi eşitsizliğin nedenleri arasında, ailesel yapı ve genetik yapı gibi maddeler görülürken okul döneminde, okul başarısı ve eğitime ulaşılabilirlik; okul sonrası dönemde ise kazanç ve meslek yer almaktadır (Psacharopoulos, 1981). Eğitimin tüm bu etmenlerle olan ilişkisinin çok güçlü olması nedeniyle hiç kuşkusuzdur ki eşitsizlik eğitimle doğrudan ilişkilidir. Bu nedenle öncelikle eğitimde yaşanan eşitsizliklerin kaynağına inmek faydalı olacaktır. Kolaşin ve Dinçer (2009), eğitimde eşitsizliğin eğitime erişim ve eğitimin kalitesi olmak üzere iki farklı boyutta incelenebildiğini; eğitime erişimde eşitsizliğin okullaşma oranı, okula devam oranı, ortalama eğitim süresi gibi niceliksel değişkenlerle ölçülürken eğitim kalitesinde eşitsizliğin ise öğrenci başarısının ölçülmesiyle değerlendirilebileceğini belirtmektedir. Eğitimde eşitsizliğin farklı nedenleri olabilmektedir. Bu nedenleri temelde sosyoekonomik altyapı kaynaklı, etnik kökene dayalı, cinsiyete dayalı, öğretmen etkisine bağlı eşitsizlikler olarak farklı gruplarda incelemek mümkündür.

\section{Sosyoekonomik Altyapıdan Kaynaklanan Eşitsizlikler}

Özellikle 60’lı 70’li yıllara kadar doğuştan gelen yeteneklerin başarı üzerindeki etkisi önemli bulunuyorken bu yıllardan sonra sosyal faktörlerin başarı üzerindeki etkisine de odaklanılmıştır (Wiggan, 2007). Eğitim eşitsizliğiyle ilgili rasyonel eylem teorileri ilk olarak 1974 yılında Raymond Boudon tarafından ortaya atılmıştır, Boudon eğitim eşitsizliğinin birincil nedenini kültürel eşitsizliklerle açıklarken Pierre Bourdieu tarafindan sosyal farklılıklar ikincil neden olarak görülmüştür (Thompson, 2016).

Bu sosyal faktörlerin başında ise sosyoekonomik altyapı gelmektedir. Kolaşin ve Dinçer'e (2009) göre, sosyoekonomik altyapının getirdiği eksileri yok edebilecek tek etmenin de eğitim olması nedeniyle sosyoekonomik altyapının eğitimde eşitsizliğe neden olup olmadığını tespit etmek önemlidir. Dünya geneline bakıldığında eğitim eşitsizliğinin ülke içindeki gelir ve bundan doğan sınıf farklılıklarından büyük oranda etkilendiği anlaşılmaktadır. Özellikle 80’lerde dünya siyaseti üzerindeki etkisini göstermeye başlayan neoliberalizmin 90’lı yıllarda

eğitim alanını da etkilemeye başlamasıyla ailelerin eğitimden beklentileri artmış, bu da dünyadaki eğitim sistemlerinin değişimine ve özel eğitim kurumlarının ortaya çımasına neden olmuştur (Lakes ve Carter, 2011). Özel eğitim kurumları ve devlet okullarının öğrencilere sunduğu imkanlardaki farklılık özel kurumlardan faydalanabilen ve faydalanamayan farklı 
gelir düzeyindeki öğrenciler arasındaki eğitim eşitsizliğiniartırmıştır.Ülkelerdekigelireşitsizliği ve eğitim eşitsizliği arasındaki ilişkiyi net bir şekilde yorumlayabilmek adına ülkelerdeki PISA sonuçlarına göre eğitim eşitsizliği oranları ve OECD datalarından elde edilen ülkelerin 'Gini' katsayıları karşılaştırılacaktır. Bu nedenle öncelikle PISA ve Gini katsayısının incelenmesi faydalı olacaktır.

Günümüzde genç neslin sahip olması gereken bazı beceriler konusunda tüm dünya hemfikirdir. $\mathrm{Bu}$ beceriler arasında bilgiyi doğru şekilde kullanma, bilgiye ulaşma, akıl yürütme, problem çözme, analiz etme yer almaktadır. PISA

\section{Özel eğitim kurumları ve devlet okullarının öğrencilere sunduğu imkanlardaki farklılık özel kurumlardan faydalanabilen ve faydalanamayan farklı gelir düzeyindeki öğrenciler arasındaki eğitim eşitsizliğini artırmıştır.} (Programme for International Student Assessment) projesi OECD ülkelerindeki gençlerin bu becerilerini ölçmeye ve ülkelerin eğitim sistemlerindeki sorunları (eğitim eşitsizliği vb.) tespit etmeye fayda sağlamaktadır. PISA sonuçlarını incelemek bu nedenle eğitim eşitsizliğini analiz edebilmek adına önemli bir araçtır. Fen bilimleri, matematik ve okuma yeterliliği ölçen sorulardan oluşan bu sınava Türkiye ilk kez 2003'te katılmıştır (Acar, 2012).

İlk olarak 1912'de kullanılmaya başlayan Gini katsayısı, popülasyonların eşitliğini sıralamak için kullanılan bir istatistiktir (Bendel, Higgins, ve Teberg, 1989). Gini katsayısının 0 olması durumu tam eşitliği, 1 olması durumu ise tam eşitsizliği ifade etmektedir. 2015-2018 yılları arası OECD ülkelerinin ortalama Gini katsayılarını gösteren veriler (World Bank Group, 2020) incelendiğindedüşük Gini katsayısına sahip(gelir eşitsizliğinin az olduğu) ülkelerin genellikle PISA 2018 testi sonucunda eğitim eşitsizliğinin az olduğu ülkelerle örtüştügü görülmektedir; ancak OECD ve PISA(OECD, PISA 2018 Results Combined Executive Summaries, 2019) verilerine göre çoğu ülke için gelir eşitsizliği ve eğitim eşitsizliği arasında pozitif bir korelasyon olduğu görülse de buna uymayan ülkelere de rastlanmaktadır. OECD dataları (OECD, PISA 2018 Results Combined Executive Summaries, 2019) incelendiğinde ortaya çıkan bir diğer veri de ülkelerin gelişmişlik düzeyi ve sınıflar arası eşitlik düzeyinin paralellik göstermesidir. $\mathrm{Bu}$ nedenle, gelişmişlik seviyesinin az olduğu ülkelerde, sınıflar arası eşitsizliğin ve bunla birlikte de eğitim eşitsizliğinin yüksek olacağı ifade edilebilir.

Türkiye için durum incelenecek olursa Türkiye'nin 2015-2018 ylları Gini ortalaması 0.40 olarak belirtilmiştir (OECD, Income inequality, 2020). Bu durumda Türkiye'nin sinıflar 
arası eşitsizliğinin ortalama bir ülke olduğunu söylemek mümkündür. PISA 2018 verileri incelendiğinde Türkiye’de sosyoekonomik altyapı olarak dezavantajlı sayılan öğrencilerle avantajlı durumda olan öğrenciler arasında 76 puanlık fark olduğu görülmüştür; ancak akademik açıdan dayanıklı (sosyoekonomik dezavantajlı olan başarılı öğrenciler) olarak nitelendirilenöğrencilerinsayısının, sınavaalınan öğrencilerin \%15’ini oluşturduğu görülmektedir. Akademik açıdan dayanıklı olarak nitelendirilen öğrenciler, sınava giren öğrenciler arasında okuma performansının en üst çeyreğinde puan alan sosyoekonomik dezavantajlı öğrencilerdir. $\mathrm{Bu}$ öğrenciler, sosyoekonomik durumun eğitim üzerindeki etkisinin değiştirilemez olmadığını göstermektedir. Diğer ülkelerin verileri incelendiğinde \%15'lik bu oran, Türkiye'deki öğrenciler için düşük sosyoekonomik durumun öğrenci başarısı üzerindeki olumsuz etkisinin diğer ülkelerdekinden daha az bir etkiye sahip olduğunu göstermektedir (OECD, 2019).

Türkiye, Gini katsayısına göre sınıf eşitsizliğinin orta dereceli olduğu bir ülke olmasına rağmen, Türkiye'de sosyoekonomik durumun öğrenci başarısı üzerindeki etkisinin birçok düşük Gini katsayılı ülkeden daha az olduğu görülmüştür. Bunun nedeni birçok düşük gelirli kişinin iş hayatına atılmasına rağmen dışarıdan ortaöğretimini sürdürüyor olmasıyla açıklanabilir. Bir diğer neden ise özellikle son yıllarda alt sınıftan kişiler içinde de okul öncesi eğitimin yaygınlaştırılması olabilir.

PISA 2018 sonuçları incelendiğinde sosyoekonomik altyapı ve eğitim eşitsizliği ile ilgili farklı başka noktalara da rastlamak mümkündür. Bunlardan ilki; Avustralya, Kanada, Danimarka, Estonya, Finlandiya, Japonya, Kore, Norveç ve Birleşik Krallık dahil olmak üzere okuma performansı yüksek olan 11 ülkenin ortalamasına bakıldığında, bu ülkelerdeki sosyoekonomik altyapının öğrenci başarısına etkisinin az olduğudur (OECD, 2019). Bu sonuçların eğitim eşitsizliği ve sosyoekonomik altyapı hakkında ortaya koyduğu bir diğer netice ise düşük sosyoekonomik altyapılı ögrencilerin beklenenden daha düşük tutkulara sahip oluşudur. Araştırma, sınavda yüksek başarı gösteren on dezavantajlı öğrenciden yedisinin yükseköğretimi tamamlamayı beklediklerini bildirirken yüksek başarı gösteren on avantajlı öğrenciden dokuzu bunu ifade etmiştir (OECD, 2019). 


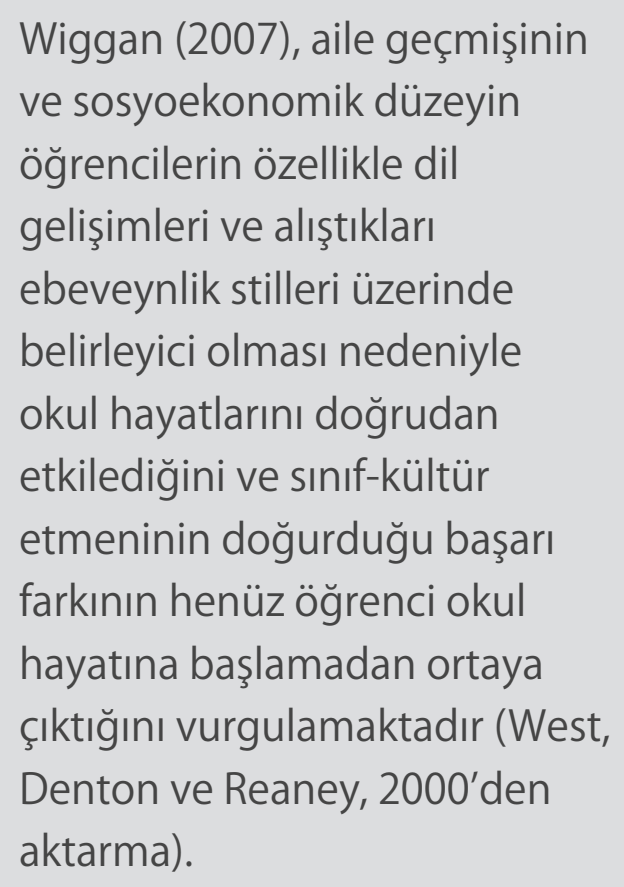

Kolaşin ve Dinçer (2009)'in PISA test sonuçlarına dayalı araştırmalarında öğrencilerin sosyoekonomik altyapıları ve sınav sonuçları arasındaki ilişkiyi incelenmiş; sonuçlar aile bireylerinin eğitimi ve istihdamı, evdeki eşyalar gibi birçok değişkenin ölçülmesiyle belirlenen sosyoekonomik durumun öğrenci başarısı üzerinde etkili olduğunu göstermiştir. $\mathrm{Bu}$ nedenle sosyoekonomik durum diğer etmenlerden bağımsız olarak değerlendirilmemelidir. Annelerin mesleklerindeki ve çalışma durumlarındaki farkllıkların, öğrencilerin okul dışındaki çalışma süre ve ortamları gibi faktörlerin de öğrenci başarısı üzerindeki eşitsizliğe neden

olduğu görülmüştür (Dronkers, 2010). Wiggan (2007), aile geçmişinin ve sosyoekonomik düzeyin öğrencilerin özellikle dil gelişimleri ve alıştıkları ebeveynlik stilleri üzerinde belirleyici olması nedeniyle okul hayatlarını doğrudan etkilediğini ve sınıf-kültür etmeninin doğurduğu başarı farkının henüz öğrenci okul hayatına başlamadan ortaya çıktığını vurgulamaktadır (West, Denton ve Reaney, 2000'den aktarma). PISA verileri kullanılarak yürütülen araştırmada görülebilen bu fark, öğrencilerin eğitim hayatlarında eşitsizliğe yol açmakta olup bireyin okulu bırakma olasılı̆̆ının artmasına ve düşük kalifikasyona neden olurken özellikle PISA 2000 sonrası verileri incelendiğinde sosyoekonomik temelli başarı farklılıklarının giderek daraldığı görülmektedir (Blanden, 2020). Özellikle 2000 sonrası okul öncesi eğitime verilen önemin artışının bunda etkili olduğu söylenebilir. Bu nedenle sosyoekonomik dezavantajlı öğrencilere okula başlamadan önce verilecek olan okul öncesi eğitim ciddi önem kazanmaktadır. Bununla birlikteeşitsizliğin çocuklar büyüdükçe de değişim gösterebildiği görülmektedir; ancak bu farklı ülkelerde farklı oranlarda karşımıza çıkmaktadır.

\section{Etnik Kökene Dayanan Eşitsizlikler}

Eğitimde yaşanan eşitsizliklerin bir nedeninin de etnik kökene dayandığı görülmektedir. Her ülkede yaşanan göç sürecine ve etnik çeşitliliğe bağlı olarak ülkedeki azınlıklar farklı oranda 
eğitim eşitsizliğine maruz kalmaktadır. Bazı ülkeler için bu farkın olmadığını, hatta göçmenlerin yerlilerden daha başarılı olduklarını bile söylemek mümkündür. Bu nedenle her ne kadar etnik köken, eğitim eşitsizliğinin altında yatan temel etmenlerden biri gibi düşünülse de aslında diğer faktörlerin (sosyoekonomik durum, okul olanakları vb.) etkisi de değerlendirilmelidir.

Hippe ve diğerleri (2016), göçmen-yerli eğitim boşluğunun temel olarak sosyoekonomik arka plandaki farklılıklar ve ev sahibi ülke dilinin bilgi eksikliği ile ilgili olduğunu, bu nedenle göçmen çocukların o ülkenin diliyle ilgili eksikliğini kapatmaya yönelik politikalar uygulaması gerektiğini ifade etmektedirler. Etnik kökene dayalı eğitim eşitsizliğinde ilgilenilmesi gereken noktalardan bir diğeri, göçmenlerin eğitimleri sürecinde yaşadıkları eşitsizliklerin nesilden nesile değişim gösterip göstermediğidir. Blanden (2020) ikinci nesil göçmenler arasındaki eğitim performansındaki farkın, yabancı doğumlu ebeveynlerin eğitim geçmişiyle bağlantılı olduğunu, özellikle de zengin ülkelerden göç alan ülkelerin eğitim açısından yerli çocuklardan daha iyi olan ikinci nesil göçmenlere sahip olduğunu belirtmektedir (Dustmann, Frattini ve Lanzara, 2012: 143-185'ten aktarma).

Günümüz dünyasında, etnik kökenin eğitim eşitsizliği üzerindeki etkisini daha rahat anlayabilmek için PISA 2018 sonuçlarının incelenmesi faydalı olacaktır. PISA 2018 raporuna göre çoğu ülkede göçmen öğrencilerin sosyoekonomik açıdan dezavantajlı oldukları görülmekte ancak Brunei Sultanlığı, Ürdün, Panama, Katar, Suudi Arabistan ve Birleşik Arap Emirlikleri'nde, göçmen öğrencilerin\%30'undan fazlasının sınava girdikleri ülkede okuma

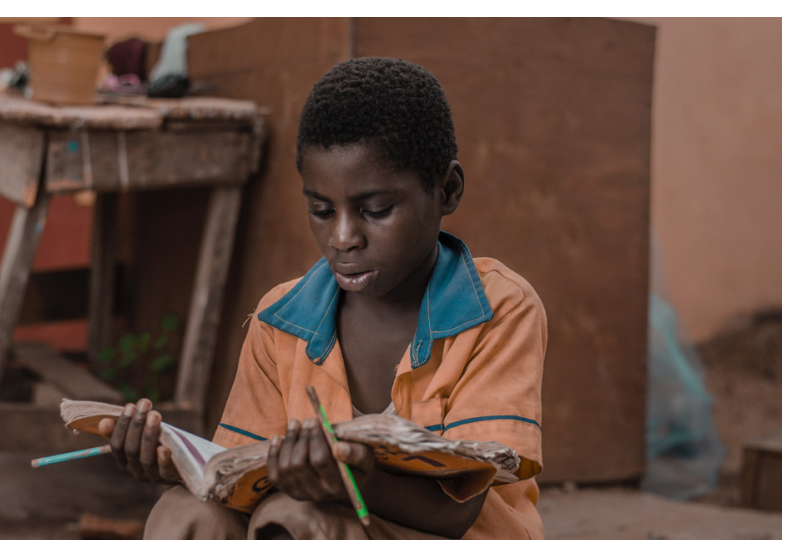
performansının ilk çeyreğinde puan almış olduğu görülmektedir (OECD, 2019). Bu da sıralanan ülkelerdeki göçmen çocukların daha başarılı oldukları anlamına gelmektedir. Türkiye'de günümüz göçmenlik ile eğitim eşitsizliği ilişkisi incelenecek olursa PISA 2018 sonuçlarına göre ortalama okuma puanı açısından göçmenler ve yerliler arasında önemli ölçüde fark olmadığı görülmektedir (OECD, 2019).

\section{Cinsiyet Temelli Eşitsizlikler}

Eğitimde eşitsizlik kavramının bir diğer boyutu da cinsiyettir. Uzun yıllardır yapılan çalışmalar cinsiyet faktörünün eğitimde eşitsizlik üzerindeki etkisini ve bunun doğurduğu sorunları ortaya koymuştur. Bazı araştırmalar, eğitimde cinsiyet kökenli eşitsizliğin doğrudan ekonomik 
büyümeyi olumsuz etkilediğini göstermektedir (Klasen, 2002). Her ne kadar son yıllarda tüm dünyada cinsiyet kaynaklı eğitim eşitsizliğinde düşüş olsa da sosyal sınıflar içerisinde düşüş olmamış ve sınıflar cinsiyet eşitsizliğini belirlemeye devam etmiştir (Breen, Luijkx, Muller, \& Pollak, 2009). Eğitim eşitsizliğinde cinsiyet faktörü incelendiğinde bunun altında ekonomik, sosyal, kültürel ve politik durumların etkilerinin yattığı görülmektedir (Jacobs, 1996). Örneğin, özellikle serbest meslek sahibi ailelerde kız çocuklar kendi istihdam olanaklarını artırabilmek için erkek çocuklara göre daha fazla eğitim alabilirken bu durum çiftçilik gibi farklı meslek grubundaki ailelerin çocukları

Çalışma sonuçları özellikle kız çocukların eğitime katılımında annenin eğitim ve çalışma durumunun, Türkçe yeterliliğinin ve babanın mesleğinin öneminin büyük olduğunu belirtirken; erkek çocuklar için bu etmenler yerine ailenin gelir durumunun ve erkek kardeş sayısının daha belirleyici olduğunu vurgulamaktadır (Smitsa \& Gündüz Hoşgör, 2006). için farklılık gösterebilmektedir (Breen, Luijkx, Muller, \& Pollak, 2009). Benzer bir durum Türkiye için de geçerlidir. Türkiye’de yürütülmüş bir araştırma cinsiyet kökenli eğitim eşitsizliği hakkında ilginç sonuçlar göstermektedir. Çalışma sonuçları özellikle kız çocukların eğitime katılımında annenin eğitim ve çalışma durumunun, Türkçe yeterliliğinin ve babanın mesleğinin öneminin büyük olduğunu belirtirken; erkek çocuklar için bu etmenler yerine ailenin gelir durumunun ve erkek kardeş sayısının daha belirleyici olduğunu vurgulamaktadır (Smitsa \& Gündüz Hoşgör, 2006). Atlama ve Özsoy (2009) ise Türkiye'deki eğitim eşitliğinin önündeki cinsiyetle ilgili engelleri geleneksel normların kadına farklı roller vermesi; maddi yetersizlikler nedeniyle eğitim alabilecek tek bir aile ferdi olması durumunda bunun erkek birey olarak seçilmesi; okullardan uzak yerleşim yerlerindeki kız çocuklarının yatılı okullara gönderilmemesi ve kadın öğretmenlerin genellikle şehirlerde çalışmayı tercih etmesi nedeniyle kız çocuklarının rol-model eksikliği yaşaması olarak sıralamıştır (KSGM, 2008a: 24; KSGM, 2008b: 30-31; UNICEF; Tan, 2000: 72-74'ten aktarma).

Günümüzde cinsiyetin eğitim başarısı üzerindeki etkisine bakılırsa PISA 2018'e katılan kız öğrencilerin okuma alanında ortalama 30 puanla erkek öğrencilerden daha iyi performans gösterdiği, erkek öğrencilerin matematikte kız öğrencilerden 5 puan daha iyi performans 
gösterdiği ve kız öğrencilerin fen alanında erkek öğrencilerden 2 puan daha iyi performans gösterdiği görülmektedir (OECD, 2019).

Cinsiyet farkının eğitim başarısı üzerindeki etksinin nedenleri incelenecek olursa PISA sonuçlarına göre tüm ülkelerde kızların erkeklere göre okumaktan çok daha fazla zevk almalarının etkili olduğu söylenebilir (OECD, 2019). Blanden (2020), İngiltere'de 11 yaşına kadar cinsiyete bağlı elde edilen başarı farklılıklarını açıklamada erken farklılıkların önemli olduğunu, erkeklerin 5 yaşında iken daha düşük dil ve ilgi düzeyleri olmasıyla açıklamaktadır (Moss, G., ve Washbrook, E., 2016).

\section{Eğitim Eşitsizliğinde Okul ve Öğretmen Etkisi}

Ball (2010) mevcut performansa ve sınav notlarına ilişkin verilere dayanarak ortalama seviyelerdeki okulların öğrenci performansında oluşturduğu farklılıkların önemsiz olup başarı farkına etkisinin sadece \%5 ile \%18 arasında değiştiğini ifade etmektedir (Wiliam, D., 2008). Örneğin, beyaz öğrencilerin siyah öğrencilere göre sayıca fazla olduğu okulların daha zengin olmasının okul olanaklarındaki farklılığa neden olmasının öğrenci başarı farkını doğurduğu düşünülse de, bu öğrencilerin benzer geçmişe sahip ailelerden gelmeleri durumunda okul farkının öğrenci başarısı üzerinde küçük bir etkisi olduğu görülmüş (Hanushek, 1986, 1989, 1991; Mosteller \& Moynihan, 1972; Spady, 1973'den aktarma), bu da okul etmeninin öğrenci başarısı üzerindeki yansımalarının arkasında yine aile geçmişi faktörünün yattığını göstermiştir (Wiggan, 2007).

Aynı durumu öğretmen faktörü için söylemek çok mümkün değildir. Okul etkisi dışında, öğrenci başarısı üzerinde öğretmen etkisini incelemeye yönelik araştırmalar da yapılmıştır. Yapılan çalışmalar öğretmen etkisinin öğrenci başarısı farklılığı üzerinde okulların sahip olduğu etkiden fazlasına sahip olduğunu göstermektedir (Ball, 2010). Andersen (2018)’a göre, öğretmenlerin not verme süreçlerinde bilişsel olmayan faktörlere önem vermesi akademik başarıyı ciddi bir şekilde düşürürken bilişsel faktörlere odaklanılması başarıyı etkilememektedir. Bununla birlikte öğretmenlerin öğrenciler üzerindeki beklenti ve önyargılarının da öğrenci başarı farkları üzerinde etkili olduğu görülmektedir (Wiggan, 2007). Hippe ve diğerleri (2016) yayımlamış oldukları raporda öğretmenlerin eğitim eşitsizliğini gidermede en önemli unsurlardan biri olduğunu, bu nedenle öğretmenlere hem ilk eğitimlerinde hem de sonraki profesyonel hayatlarında verilecek bilimsel ve pedagojik eğitimin çok önemli olduğunu ifade etmektedirler.

Tüm bunlara rağmen yürütülen bir araştırma daha nitelikli öğretmenlerin yüksek başarı gruplarına atanma eğiliminde olduğunu göstermiştir (Francis, 2019). Bu durumu destekleyen başka bir çalışma iseözellikle deneyimli öğretmenlerin sınıflarına daha az sayıda siyahi ve düşük 
ders notlarına sahip öğrenci atanırken; çoğunlukla daha az devamsızlığa sahip, ortalamaları yüksek öğrenciler atandığını ve bu durumun öğrenciler arasındaki eşitsizliğin daha da artmasına yol açtı̆̆ını vurgulamaktadır (Grissom, Kalogrides, ve Loe, 2015).

Yürütülen araştırmalar

daha nitelikli öğretmenlerin

yüksek başarı gruplarına

atanma eğiliminde olduğunu

göstermiştir (Francis, 2019).

\section{Türkiye’de Eğitim Eşitsizliğini Önlemeye Yönelik Politikalar}

Eğitim politikalarının öğrenciler arası eşitsizliği azaltabildiği gibi arttırabildiğini savunan araştırmacılar da mevcuttur. Örneğin Ball (2010), üstün zekalı ve özel yetenekli öğrenciler için geliştirilen farklılaştırılmış programlar gibi "standartları yükseltmeyi” amaçlayan programların dış eşitsizlikleri daha da arttırdığını vurgulamaktadır (Gillborn ve Youdell, 2000'den aktarma). $\mathrm{Bu}$ nedenle eğitim eşitsizliğini olabildiğince azaltmak için izlenecek politikaların planlaması önemlidir.

Dünya Bankası́nın 2011'de yayımladığı raporda Türkiye eğitim eşitsizliğinin yüksek olduğu bir ülke olarak tanımlanmıştır. 2018 PISA sonuçlarına bakıldığında ise Türkiye’deki öğrenciler için düşük sosyoekonomik durumun öğrenci başarısı üzerindeki olumsuz etkisinin diğer ülkelerdekinden daha az bir etkiye sahip olduğu görülmüştür. Bu veri, arada geçen 7 yıllık süreçte benimsenen eğitim politikalarının olumlu sonuçlarının görülmeye başladığını kanıtlamaktadır. Bu nedenle 2011'de Dünya Bankası tarafından yayımlanan raporda değinilmiş olan eğitim eşitsizliğini engellemeye yönelik benimsenen politikaların neler olduğunun anlaşılması önem kazanmaktadır. Rapordaki politikalarda okul öncesi eğitim, öğretmen, finans ve bilgi olmak üzere dört başlığa önem verilmiştir (World Bank Human Development Department, 2011). Bu politikalardan ilki incelendiğinde okul öncesi eğitimin yaygınlaştırılmasına ciddi derecede önem verildiği, okul öncesi eğitimin önemi konusunda aileleri bilinçlendirmeye yönelik kampanyalar düzenlendiği anlaşılmaktadır. Raporda değinilen bir diğer politikanın ise öğretmen kalitesini arttırmaya yönelik olduğu anlaşılmaktadır. Bu doğrultuda öğretmenlere ilk yıllarında destek verilmesi, ögrretmen motivasyonunu arttırmak adına maddi ve maddi olmayan teşviklerin oluşturulması, öğretmenlere hizmet içi eğitimlerin geliştirilmesi gibi uygulamalara yer verilmiştir. Benimsenen politikalardan bir diğeri ise finansa yöneliktir. Halk eğitimini finanse edebilmek adına bir sistem geliştirmek, kamu kaynaklarını en çok ihtiyacı olan grupların eğitimine hedeflemek ve yüksek öğretime giriş sisteminde değişiklik yapılması bu politikanın sonuçlarındandır. Raporda değinilen son politikanın ise bilgi artışını sağlamaya 
bireylere (yoksul, azınlık ve engelli) okul öncesi eğitim sağlanmalıdır. Özellikle, On Birinci Beş Yıllık Kalkınma Planı incelendiğinde okul öncesi eğitimin zorunlu hale getirilmesinin hedeflendiği erken çocukluk eğitiminde 5 yaşın zorunlu eğitim kapsamına alınmasının yönelik olduğu görülmektedir. Özellikle, bazı bölgelerde öğrencilerin kimlik kartının geç çıkarılışı gibi ya da uzun süre çıkartılmayışı gibi noktalar, eğitime kaydettirilmesi gereken öğrencilere erişilmesini zorlaştırmaktadır. $\mathrm{Bu}$ doğrultuda, halkın eğitim üzerine tartışmasını teşvik edebilmek adına her yıl çıkarılacak yıllık rapor, her okulla ilgili verilerin bulunduğu belgelerin halka ulaştırılması ve kaliteyi arttırabilmek adına verilerin toplanacağı e-okul veri tabanının oluşturulması planlanmıştır.

Yapılan literatür taramasından da anlaşılabileceği üzere eğitimde eşitsizliğin nedeni ne olursa olsun öğrencilerin okula başlarken nasıl bir ön birikimle geldiğinin büyük önemi olduğu görülmektedir. Sosyoekonomik altyapı nedeniyle yaşıtlarından daha dezavantajla eğitim almaya başlayan bireyin bu farkı kapatabilmesi son derece zor olmakta, öğrencilerin okula başlamadan önce diğer bireylerden geri kalmamasını sağlamak önem kazanmakta ve okul öncesi eğitimin ya da dezavantajlı bireylerin de erişebileceği eğitim materyallerinin herkese sağlanması önem kazanmaktadır. Bu nedenle mutlaka her bölgeye ve özellikle dezavantajlı planlandığı görülmektedir (Türkiye Cumhuriyeti Cumhurbaşkanlığı Strateji ve Bütçe Başkanlığı, 2019). Bu maddenin hayata geçirilmesinin, sosyoekonomik kökenli eğitim eşitsizliğini azaltacağı öngörülmektedir. Bunun dışında, her sosyoekonomik düzeyden bireyin ulaşabileceği kanalların etkin bir biçimde kullanılması; belediyelerin, radyo ve televizyonların her yaş grubu ebeveyni için okul öncesi süreçle ve kişisel gelişimle ilgili düzenli eğitimler gerçekleştirmesi de sosyoekonomik kökenli eğitim eşitsizliğini azaltmada büyük rol oynayacaktır.

Bunun dışında kaliteyi sağlamaya yardımcı olabilecek politikalara odaklanmak da eşitsizliğin azaltılmasında büyük etkiye sahiptir (Walker, Pearce, Boe, ve Laws, 2019). Öğretmen niteliğini arttırmaya, kaliteli olan ve ayrımcı olmayan öğretim materyalleri üretmeye yönelik politikalar izlenmelidir. Kız çocuklarının ve kadınların evde kalıp farklı sorumluluklar yüklenmelerine neden olan algıları yıkabilmek için eğitim programlarının eşitlikçi toplumsal cinsiyet rollerini teşvik etmesini sağlayacak içeriklere yer vermesi sağlanmalıdır. “Öğretmenlerin işe alım süreçlerinin revizyonu, yüksek ihtiyaç okullarındaki öğretmenlere daha fazla ödenmesi, görev sürelerinin yeniden planlanması, nitelikli müdürlerin en çok ihtiyaç duyan yerlere atanması ve dezavantajlı bölgeler için öğretmen çalışma koşullarının iyileştirilmesi” kısa sürede öğretmen niteliğini artırmayı sağlayabilecek önlemler olarak ifade edilirken; "tazminatların düzenlenmesi, veri sistemlerinin yapılandırılması ve 
öğretmen hazırlık programlarının değerlendirilmesi” daha uzun süreli hedefler arasında gösterilmektedir (Peske \& Haycock, 2006).

Eğitim eşitsizliğinde etkili olan faktörlerden bir diğerinin ise okul olduğu yukarıda tartışılmıştır. Özellikle eğitim eşitsizliğinin çok az olduğu ülkelerin başında gelen Finlandiya incelendiğinde; ülkedeki tüm okulların devlet okulu olduğu, Finlandiya eğitim sisteminde özel okulların sadece din eğitimi sağladığı ve bu nedenle tüm okulların birbirine yakın kalitede eğitim sağladığı görülmektedir. (Özdemir, 2017). Özel okulların devlet okullarıyla farklı kalitede eğitim yürütmesi sorununun çözülmesi bu yüzden önem kazanmaktadır. Bunun için en başta çok sayıda okul yapılarak devlet okullarındaki sınıf mevcutları azaltılmalıdır. Okul eksikliğinin giderilmesi için seferberlik düzeyinde bir hamleye ihtiyaç vardır. Mevcut devlet okullarına öğrencilerin sığmaması nedeniyle metropollerde ikili eğitim gibi eğitim açısından uygun olmayan süreçler yürütülmeye çalışılmaktadır. Bunun dışında, özel okulların sayıca artışı her ne kadar devletin yükünü maddi açıdan önemli ölçüde azaltmayı sağlasa da özel okulların sundukları imkanlar, fiziksel şartlar, derslikteki öğrenci sayısı gibi farklılıklar, devlet okullarında okuyan öğrencilerle özel okullarda okuyan öğrenciler arasındaki eğitim eşitsizliğini genişletmektedir. Bu nedenle, okul öncesi eğitimden orta öğretime (12 yıl) evrensel, ücretsiz, eşitlikçi ve yüksek kaliteli eğitim sağlamak için planlar yapılması önemlidir (Walker, Pearce, Boe, ve Laws, 2019). Özel kurumların devamlılığı sağlanacaksa bile bu kurumlarla devlet okullarının izleyeceği eğitim planlarının farklı olmaması sağlanmalı ve takibi sürdürülmelidir. Özellikle devlet okullarının sayı ve olanaklarının artırılması bu doğrultuda elzemdir. Bu doğrultuda, On Birinci Beş Yıllık Kalkınma Planı’nda “tüm eğitim kademelerinde okullaşma ve tamamlama oranları artırılacak”, "tüm eğitim kademelerinde okulların niteliği ve imkânları artırılarak okullar arası başarı farkı azaltılacaktır” maddeleri görülmektedir (Türkiye Cumhuriyeti Cumhurbaşkanlığı Strateji ve Bütçe Başkanlığı, 2019).

Eğitim eşitsizliğini azaltmaya yönelik sağlanması gerekli olan bir diğer nokta ise ekonomik homojenliktir. Yine Finlandiya'yı eğitim eşitliği sağlayabilme açısından avantajlı kılan etmenlerden biri, Finlandiya'nın ekonomik homojenliğinin yüksek oluşudur (Hart, 2017). Bunda halkın geliri en yüksek ve en düşük bireyleri arasında çok büyük fark olmayışının etkisi yüksektir.

Diğer önemli nokta ise hükümetlerin eğitimde kalite ve eşitlik sağlamak için 
yaptığı harcamalardır. Düşük ve orta gelirli ülkelerde, hükümet bütçelerinin en az \%20'sini veya eğitime tahsis edilen GSMH'nin \%6'sı bu hedef için ayrılmalıdır (Walker, Pearce, Boe, ve Laws, 2019). Tüm bunların sağlanması hemen olmasa da uzun vadede eğitimde eşitsizliği azaltmada önemli rol oynayacaktır.

\section{Sonuç}

Çağımızın en büyük sorunlarından biri eğitimin bir hak olmasına rağmen bireyler arasında yaşanan eğitim eşitsizliğidir. Eğitim eşitsizliğinin yansımaları birçok farklı şekilde ölçülebilmektedir. Bu ölçümler sonucu yapılan analizler eğitim eşitsizliklerinin sosyoekonomik durum, cinsiyet, göçmenlik gibi faktörlerden etkilenebildiğini göstermektedir. Eğitim eşitsizliğini azaltabilmek ve her bireyin hak olan eğitimden eşit derecede yararlanabilmesini sağlamak için öncelikle o ülkede eğitim eşitsizliğine yol açan faktörlerin analizi önemlidir. Ancak eğitim eşitsizliğinin altında yatan nedenlerin anlaşılmasıyla o sorunu çözebilecek nitelikte kararlar alınıp politikalar yürütülebilir. Dört yılda bir uygulanan PISA sınavlarının gösterdiği sonuçlardan biri de ülkelerdeki eğitim eşitsizliğinin derecesi ve eşitsizliğin temelinde yatan nedenlerdir. $\mathrm{Bu}$ nedenle eğitimde eşitsizlik sorununu en aza indirgeyebilmek için PISA raporlarının analizi elzemdir.

Türkiye için son on yıllık süreç incelendiğinde eğitimde eşitsizliğin azaltılması adına büyük adımlar atıldığını söylemek mümkündür. Bu doğrultuda, önceki yıllarda eğitim eşitsizliğinin temelini oluşturan sorunların iyi analiz edildiği ve doğru kararlar alındığı söylenebilir. Çözülmemesi durumunda bir kısır döngüyüde beraberinde getiren eğitim eşitsizliği öğretmen kalitesi, okul öncesi eğitim politikaları, eğitime ayrılan bütçe gibi faktörlerin artmasıyladüşüş göstermiştir; ancak yine de eğitimde eşitsizliğin hiç olmadığı ya da minimum düzeyde olduğu söylenemez. Örneğin devlet okullarına yeterli bütçe ayrılmaması, ödenek gönderilmemesi, hala personel temizlik gibi zorunlu giderlerin aile birliklerine bırakılması, bu durumunda okulun bulunduğu semte göre arada uçurumların olması, okul müdürlügünün bir kadroya bağlı olmayıp öğretmene verilen ikinci bir görev olarak yürüttürülmesi konuları hala çözüm bekleyen kronik problemlerdir. Bu nedenle, dinamik bir süreç olan eğitimin her an eşitlik anlamında da kontrolünün sağlanması ve doğru kararlar alınarak uygulanmaya devam etmesi eğitim eşitsizlğini en aza indirgemek adına önemlidir. 


\section{Kaynakça/References}

Acar, T. (2012). Türkiye’nin PISA 2009 sonuçlarına göre OECD’ye üye ve aday ülkeler arasındakiyeri. Educational Sciences: Theory \& Practice, 12(4), 2561-2572.

Andersen, I. G. (2018). Pygmalion in instruction? Tracking, teacher reward structures, and educational inequality. Social Psychology of Education, 21, 1021-1044. doi:10.1007/s11218-018-9452-z

Atlama, S., \& Özsoy, C. (2009). Eğitimde toplumsal cinsiyet eşitsizliği: Türkiye’nin karşılaştırmalı analizi. İ. G. Yumuşak içinde, Uluslararası 7. Bilgi, Ekonomi Ve Yönetim Kongresi Bildirileri Kitabı (s. 2-73). İstanbul: FSM-İstanbul.

Ball, S. J. (2010). New class inequalities in education. International Journal of Sociology and Social Policy, 30(3/4), 155-166. doi:10.1108/01443331011033346

Bendel , R. B., Higgins, S. S., ve Teberg, J. E. (1989). Comparison of skewness coefficient, coefficient of variation, and Gini coefficient as inequality measures within populations. Oecologia, 394-400.

Blanden, J. (2020). Education and inequality. S. Bradley, \& C. Green içinde, The Economics of Education (s. 119). Londra: Academic Press.

Breen, R., Luijkx, R., Muller, W., \& Pollak, R. (2009). Long-term trends in educational inequality in Europe: class inequalities and gender differences. European Sociological Review, 1-18.

Dinçer, M. A., \& Kolaşin, G. (2009). Türkiye'de öğrenci başarısında eşitsizliğin belirleyicileri. İstanbul: Sabancı Üniversitesi .

Dronkers, J. (2010). Quality and Inequality of Education. New York: Springer. doi:10.1007/978-90-481-39934

Francis, B. v. (2019). Teacher 'quality' and attainment grouping: The role of within-school. Teaching and Teacher Education, 77, 183-192. doi:https://doi.org/10.1016/j.tate.2018.10.001

Grissom, J., Kalogrides, D., \& Loe, S. (2015). The micropolitics of educational inequality: the case of teacherstudent assignments. Peabody Journal of Education, 90(5), 601-614.

Hart, J. (2017). The big lesson from the world's best school system? Trust your teachers. TheGuardian: https:// www.theguardian.com/teacher-network/2017/aug/09/worlds-best-school-system-trust-teacherseducation-finland adresinden alınd 1

Hippe, R., Araújo, L., ve Dinis da Costa , P. (2016). Equity in education in Europe. Luxembourg: European Comission.

Jacobs, J. A. (1996). Gender inequality and higher education. Annu. Rev. Sociol, 22, 153-185.

Klasen, S. (2002). Low schoolings for girls, slower growth for all? Cross-country evidence on the effect of gender inequality in education on economic development. The World Bank Review, 16(3), 345-373.

Lakes , R., \& Carter, P. (2011). Neoliberalism and education: An introduction. EducationalStudies, 107-110.

OECD. (2019). PISA 2018 Results Combined Executive Summaries. OECD:http://www.oecd.org/pisa/ Combined_Executive_Summaries_PISA_2018.pdf adresinden alındı

OECD. (2020). Income inequality. doi:10.1787/459aa7f1-en

Özdemir, A. (2017). Bütünöğrencilerin okulu Finlandiya okulları. Journal of Research in Informal Environments, 2(1), 59-91.

Peske, H., \& Haycock, K. (2006). Teaching inequality: how poor and minority students are shortchanged on teacher quality. Washington: Education Trust.

Psacharopoulos, G. (1981). Education, employment and inequality in LDCs. WorldDevelopment, 9, 31-54.

Smitsa, J., \& Gündüz Hoşgör, A. (2006). Effects of family background characteristics on educational participation in Turkey. International Journal of Educational Development, 26, 545-560.

Thompson, R. (2016). Understanding classbased inequalities in education: rational action theories 
of educational decision making. Society for Research into Higher Education (SRHE) Annual Conference 2016, (s. 3). Newport.

Türkiye Cumhuriyeti Cumhurbaşkanlı̆̆ı Strateji ve Bütçe Başkanlığı. (2019). On Birinci KalkınmA Planı. Ankara.

Walker, J., Pearce, C., Boe, K., ve Laws, M. (2019). The power of education to fightinequality. Oxford: OXFAM.

Wiggan, G. (2007). Race, school achievement, and educational inequality: toward a student-based inquiry perspective. Review of Educational Research, 77(3), 310-333. doi:10.3102/003465430303947

World Bank Group. (2020). Gini index (World Bank estimate). The World Bank: https://data.worldbank.org/ indicator/SI.POV.GINI adresinden alındı

World Bank Human Development Department. (2011). Improving the quality and equity ofbasic education in Turkey. Washington: World Bank.

Yılmaz, T., ve Sarpkaya, R. (2016). Eğitim Ekonomisi Eleştirel Bir Yaklaşım. Ankara: Anı. 